\title{
Heterotrophic Bacterial Population in Acid Coal Mine Water: Flavobacterium acidurans
}

\author{
sp. n. ${ }^{1}$
}

W. N. MILLAR

\begin{abstract}
Division of Plant Sciences, West Virginia University, Morgantown, West Virginia 26506
\end{abstract}
\begin{abstract}
Acid water from a closed deep coal mine was examined for the presence of heterotrophic bacteria. This water, which is routinely pumped to a surface stream for runoff, did not contain "acid streamers" or slime-producing, sporeforming bacteria. However, aerobic, nonmotile, yellow, nonfermentative, gram-negative rods were found by using the most-probable-number technique with a dilute tryptone-yeast extract medium. The isolates displayed binary fission as the mode of reproduction although abortive division, as evidenced by mini-cell formation, occurred at a low frequency. Based on morphological and other characteristics, including deoxyribonucleic acid base composition, a new species, Flavobacterium acidurans, is proposed for these bacteria. The type strain of this organism is ATCC 27383. Periodic sampling of mine effluent over a 1-year period disclosed that this organism comprises a major microbial component of the acid environment.
\end{abstract}

Drainage of acid waters from coal mines is a serious pollution problem in Appalachia due to the high levels of iron, sulfate, and hydrogen ions in these waters. These components are derived, in part, from oxidations of reduced iron and sulfur compounds, such as pyrite and marcasite, by members of the genera Thiobacillus and Ferrobacillus (4). Such iron-oxidizing bacteria possess a chemolithotrophic nutrition. They grow in the complete absence of preformed organic compounds if ferrous iron, carbon dioxide, and mineral salts are supplied. One consequence of such growth, however, is the release of organic compounds into the surrounding medium. For example, Schnaitman and Lundgren (25) found that $9.6 \%$ of the carbon dioxide fixed by Ferrobacillus ferrooxidans was released extracellularly.

Because organic matter is liberated by $F$. ferrooxidans during growth, the possibility exists that acid mine water may support the growth of heterotrophic bacteria. Dugan et al. (7) investigated this possibility with $\mathrm{pH} 2.8$ water from an Ohio coal mine that displayed "acid streamers." From such streamers five gram-negative bacteria, two gram-positive bacteria, and one yeast were isolated (8). One of the isolates, a Bacillus species, was shown to be

\footnotetext{
${ }^{1}$ Published as West Virginia University Agricultural Experiment Station Scientific Paper No. 1240.
}

responsible for production of the acid streamers. The gram-negative isolates, however, could not be maintained for more than three transfers in the laboratory.

The purpose of the present study was to determine whether acid coal mine water that lacked streamers also possessed an indigenous heterotrophic bacterial microflora.

\section{MATERIALS AND METHODS}

Mine water. The acid mine water examined was the effluent from a pump, which removes water from the Pursglove no. 15 Mine. This mine, located about 5 miles (about $8 \mathrm{~km}$ ) north of Morgantown, W. Va., and owned by the Christopher Coal Co., has been closed for approximately 20 years. Over the past 2 years the pump, operating semicontinuously, has eliminated an average of 800,000 gallons (about $3,028,000$ liters) of water each day. The water has a $\mathrm{pH}$ of 2.6 and, because it is drawn from a depth of 292 feet (about 89 meters), has a constant temperature of $20 \mathrm{C}$.

Sampling procedure. Water samples were collected in sterile Erlenmeyer flasks directly from the mouth of the pump to minimize chances of introducing microorganisms not indigenous to the mine water. The flasks, filled to capacity to prevent oxidation during transportation to the laboratory, were examined bacteriologically and chemically within $2 \mathrm{~h}$ after collection.

Chemical determinations. Total dissolved iron levels in mine water samples were determined using the 1,10-phenanthroline method described (catalog no. 
10, 1969, Hach Chemical Company, Ames, Iowa) for a Hach DR Colorimeter. Sulfate ion concentrations were assayed by the barium sulfate turbidimetric method, also according to the Hach procedure.

Isolation and enumeration of bacteria. All bacterial populations in acid mine water were enumerated by eight-tube, most-probable-number (MPN) series after incubation for 21 days at $20 \mathrm{C}(19)$. For iron-oxidizing chemolithotrophic bacteria, $9 \mathrm{~K}$ medium was employed (27), and for the sulfur-oxidizing chemolithotrophic bacteria, $9 \mathrm{~K}$ basal salts medium containing elemental sulfur was used (31).

Initial attempts at isolating heterotrophic bacteria from the mine pump included five- or eight-tube MPN series with the following media: filter-sterilized acid mine water containing $0.1 \%$ yeast extract, $\mathrm{pH} 3.0$ and 7.0; medium no. 3 of Postgate (21) for sulfate-reducing bacteria, $\mathrm{pH} 4.5$ and 7.6 ; soil extract broth (14), pH 3.3 and 7.3 ; thioglycolate medium, pH 7.0; tryptic soy broth, $\mathrm{pH} 3.3,4.8$, and 6.6 ; and a broth composed of $0.1 \%$ each tryptone and yeast extract, $\mathrm{pH} 3.4,5.2$, and 7.0. In these trials heterotrophic bacteria were isolated only with the tryptone-yeast extract broth at $\mathrm{pH}$ values of 5.2 and 7.0. It was subsequently determined that the greatest number of heterotrophic bacteria could be isolated from the pump samples using a medium (TYE) of the following composition: tryptone, $0.1 \%$; yeast extract, $0.1 \% ; \mathrm{Na}_{2} \mathrm{SO}_{4}, 0.1 \%$; $\mathrm{pH} 6.0$ with sulfuric acid. Heterotrophic isolates were obtained by streaking organisms from those positive MPN tubes at the highest dilutions onto TYE solidified with $2.0 \%$ agar. For characterization purposes, 15 isolates were selected from seven different pump samples collected over a period of six months (Table 1). After initial isolation, all heterotrophic cultures were grown in TYE at $25 \mathrm{C}$ and stored at 4 C. Working cultures were transferred at 3-week intervals.

Growth of heterotrophs in acid mine water. A modified replacement culture technique was employed to demonstrate growth of the heterotrophic bacteria in $\mathrm{pH} 2.6$ acid mine water. This approach was adopted since the pump samples contained insufficient organic carbon $(8.2 \mathrm{mg} /$ liter, D. H. Rothermel and W. N. Millar, unpublished data) to support significant heterotrophic growth in batch culture. Flasks containing distilled water, $9 \mathrm{~K}$ medium, and filter-sterilized acid mine water, each at $\mathrm{pH} 2.6$, were inoculated with washed cells (isolate number 1-51-22) and incubated for 13 days at $25 \mathrm{C}$ on a reciprocal shaker. At four different times during incubation, $20 \%$ of the contents of each flask was removed and replaced with sterile medium of similar composition. This resulted in a net physical removal of approximately $60 \%$ of the original flask contents. MPN determinations in TYE were performed before and after the incubation period to determine population levels. Small numerical changes or a numerical gain during incubation in the flasks would indicate heterotrophic growth and multiplication. In contrast, numerical losses of $60 \%$ or more of the initial population would indicate that the heterotrophs were unable to grow.

Biochemical tests. Final interpretations of all growth and biochemical determinations were made after incubation for 21 days at $25 \mathrm{C}$. Catalase
TABLE 1. Strain designations of isolated acid mine water heterotrophs

\begin{tabular}{|c|c|}
\hline Strain & Water sampling date \\
\hline $1-39-26$ & July 24,1970 \\
\hline $1-39-29$ & $\ldots \ldots \ldots \ldots$.July 24,1970 \\
\hline $1-41-14$ & $\ldots \ldots \ldots \ldots \ldots$. . September 1,1970 \\
\hline $1-41-15$ & $\ldots \ldots \ldots \ldots$. Weptember 1,1970 \\
\hline $1-42-12$ & $\ldots \ldots \ldots \ldots$ September 27,1970 \\
\hline $1-42-13$ & $\ldots \ldots \ldots \ldots$ September 27,1970 \\
\hline $1-47-11$ & $\ldots \ldots \ldots$ October 14,1970 \\
\hline $1-47-24$ & .... October 30,1970 \\
\hline $1-47-27$ & $\ldots$ October 30,1970 \\
\hline $1-51-7$ & November 16,1970 \\
\hline $1-51-10$ & . . November 16,1970 \\
\hline $1-51-22$ & . December 2,1970 \\
\hline $1-51-23$ & $\ldots \ldots \ldots \ldots \ldots$ December 2,1970 \\
\hline $1-51-31$ & $\ldots \ldots \ldots \ldots \ldots$ December 2,1970 \\
\hline $1-51-32$ & $\ldots \ldots \ldots \ldots$. . . December 2,1970 \\
\hline
\end{tabular}

determinations were made by adding $3 \% \mathrm{H}_{2} \mathrm{O}_{2}$ to cells grown on TYE agar. The oxidase test (16), interpreted according to the criteria of Steel (29), and the benzidine test for iron porphyrins (5) were performed to determine the presence of a cytochrome system. The phosphatase test was performed on TYE agar containing $0.01 \%$ phenolphthalein diphosphoric acid (2).

The hydrolysis of gelatin and starch and the utilization of tyrosine and xanthine were examined with TYE agar containing the appropriate substrate. Lipolytic activity was evaluated by adding $1.0 \%$ Tween 60 and $0.01 \% \quad \mathrm{CaCl}_{2} \cdot \mathrm{H}_{2} \mathrm{O}$ to TYE agar. Cellulose hydrolysis was examined by placing a filter paper strip into tubes of TYE.

Hydrogen sulfide production was examined in SIM Medium (Difco, Detroit, Mich.) initially adjusted to $\mathrm{pH}$ 6.0. Indole production and nitrate reduction were determined in TYE supplemented, respectively, with $1.0 \%$ tryptone and $0.1 \% \mathrm{KNO}_{3}$. Brain Heart Infusion, Casamino Acids, heart infusion broth, Koser citrate medium, litmus milk, MR-VP medium, neopeptone, nutrient broth, proteose peptone, soytone, thioglycolate medium, tryptic soy broth, tryptone, tryptose broth, urea broth, and yeast extract were Difco products.

Tests for autotrophic growth of the acid mine water heterotrophs were made in the salts solution of Starkey (28) containing either thiosulfate $(0.5 \%)$ or sulfur $(1.0 \%)$ at $\mathrm{pH}$ 6.0. In addition, the thiosulfatecontaining media of Charles and Suzuki (3), Santer et al. (23), and Trautwein (30) were used, as were the media described above, for the enumeration of iron-oxidizing and sulfur-oxidizing chemolithotrophs. To determine a possible mixotrophic utilization of sulfur and thiosulfate, tubes of Starkey thiosulfate and sulfur media containing $0.1 \%$ each of tryptone and yeast extract were employed.

The utilization of single organic compounds as sole sources of carbon was investigated using a mineral salts medium (MS) of the following composition:

$\mathrm{MgSO}_{4} \cdot 7 \mathrm{H}_{2} \mathrm{O}, 0.2 \mathrm{~g} ; \mathrm{FeSO}_{4} \cdot 7 \mathrm{H}_{2} \mathrm{O}, 0.04 \mathrm{~g} ; \mathrm{Na}_{2} \mathrm{SO}_{4}$, $1.0 \mathrm{~g} ; \mathrm{NaMoO}_{4} \cdot 2 \mathrm{H}_{2} \mathrm{O}, 0.04 \mathrm{~g} ; \mathrm{MnSO}_{4} \cdot \mathrm{H}_{2} \mathrm{O}, 0.04 \mathrm{~g}$; 
$\mathrm{KCl}, 0.1 \mathrm{~g} ; \mathrm{NH}_{4} \mathrm{NO}_{3}, 1.0 \mathrm{~g} ; \mathrm{H}_{2} \mathrm{O}, 1,000 \mathrm{ml} ; \mathrm{pH} 6.0$. The organic compounds, sterilized by filtration, were added to the medium at a final concentration of $0.2 \%$. The utilization of nitrogen-containing organic compounds as sole sources of carbon and nitrogen was investigated using MS medium without the $\mathrm{NH}_{4} \mathrm{NO}_{3}$. The nitrogen-containing organic compounds were either membrane filtered or autoclave sterilized and added to give a final concentration of $0.2 \%$.

Acid production from carbohydrates and polyalcohols (13) was determined using basal media of TYE and one-tenth strength TYE with $0.002 \%$ bromocresol purple as an indicator. All carbohydrates and polyalcohols were membrane filter sterilized as $10 \%$ (wt/vol) solutions and added to the basal media to give final concentrations of $0.5 \%$.

Susceptibility to antibiotics was determined using Sensi-Discs (BBL) on heavily seeded TYE agar plates. Sensitivity to the vibriostatic compound $0 / 129(2,4$ diamino-6,7-diisopropylpteridine) was assayed by applying the crystals to the surface of spread plates.

Deoxyribonucleic acid base composition. Duplicate analyses of the guanine plus cytosine contents of the deoxyribonucleic acid (DNA) of representative isolates growing on TYE agar were performed by $M$. Mandel by means of the $\mathrm{CsCl}$ density gradient method (24).

Electron microscopy. Whole-cell observations were made on cells mounted on carbon-supported Formvar grids and stained with $1 \%$ uranyl acetate. For sectioning, cells grown in TYE were centrifuged and fixed overnight $(16 \mathrm{~h})$ in $1 \% \mathrm{OsO}_{4}$ (15). The fixed preparations were dehydrated in a graded ethanol series, embedded in Epon 812 (17), and sectioned with a glass knife. The sections were post-stained with $2 \%$ uranyl acetate and lead citrate (22) and observed in an RCA EMU-36 electron microscope at $100 \mathrm{kV}$.

\section{RESULTS}

Occurrence. Pump effluent was sampled over a 1-year period for counts of heterotrophic and chemolithotrophic bacteria as well as for concentrations of iron and sulfate ions. Fig. 1 shows that major fluctuations of these parameters did not occur over the sampling period. The fact that all bacterial populations were able to maintain stable population levels despite dilution by influx of ground waters and elimination by pump action suggests that they are able to multiply in this environment. The $\mathrm{pH}$ (2.6) and temperature (20 C) of the effluent did not vary during the sampling period.

Cell and colony morphology. All isolates were gram-negative, procaryotic rods, 0.3 to 0.6 by 1.0 to $3.0 \mu \mathrm{m}$ (Fig. 2). Spores, branching, and motility were not detected in any of the strains under the cultural conditions used. The division process was constrictive in nature with no initial formation of a transverse septum. Occasionally multiple constrictions occurred, resulting in the formation of very small cells (Fig. 3). Such small structures were evident on
1 to $5 \%$ of the cells during growth in TYE and were observed in both polar and nonpolar configurations. Because thin sections through these small structures revealed the absence of DNA, it is believed that they are "mini-cells" (1). Mini-cells are small, anucleate bodies resulting from the asymmetric segregation of cytoplasmic material during division. Culture filtrates passed through $0.45-\mu \mathrm{m}$ membrane filters were unable to initiate growth in fresh TYE.

All isolates were slow growing. Growth was rarely noticeable to the unaided eye after incubation for 1 week, 4 weeks being required for the isolates to attain a maximum colony diameter of $1 \mathrm{~mm}$ on TYE agar. Such colonies were characterized by a pale, yet distinct, yellow, water-insoluble pigment.

Growth conditions. Because initial attempts to isolate heterotrophic bacteria from acid mine water using several heterotrophic media were unsuccessful, the ability of isolated heterotrophs to grow in a number of conventional nutritive media was investigated (Table 2 ). In trial I, where the initial $\mathrm{pH}$ values of the media were not altered, few of the media examined were able to support growth of all the isolates. In trial II, similar media were adjusted initially to $\mathrm{pH} 6.0$ by the addition of sulfuric acid. In this latter case most of the media examined supported growth of the heterotrophs. Tryptic soy broth and Brain heart infusion were unable to support growth of the heterotrophs even at pH 6.0.

Because none of the media examined provided better growth of the isolates than TYE, this medium was used to determine temperature and $\mathrm{pH}$ ranges for growth. As recorded in Table 3, the heterotrophs were mesophilic with none able to grow at $45 \mathrm{C}$. Growth of all isolates also occurred between $\mathrm{pH}$ values of 4.5 and 6.5. The lack of turbidity at $\mathrm{pH}$ values of 3.5 and below was unexpected since the heterotrophs were apparently indigenous to waters at $\mathrm{pH}$ 2.6. This apparent anomaly was investigated by a replacement culture technique using acid mine water at $\mathrm{pH} 2.6$ as the growth medium. Table 4 shows that the heterotrophic populations in distilled water and $9 \mathrm{~K}$ medium (both at $\mathrm{pH} 2.6$ ) decreased in excess of the expected $60 \%$. These losses are probably due to starvation and to the effects of hydrogen and iron ions. In the case of the filter-sterilized acid mine water medium, no such loss of viable cells occurred. Such a result is explained only by the growth of the heterotrophic bacteria at $\mathrm{pH} 2.6$ under the low nutrient conditions of acid mine water.

Biochemical characteristics. The isolates were 


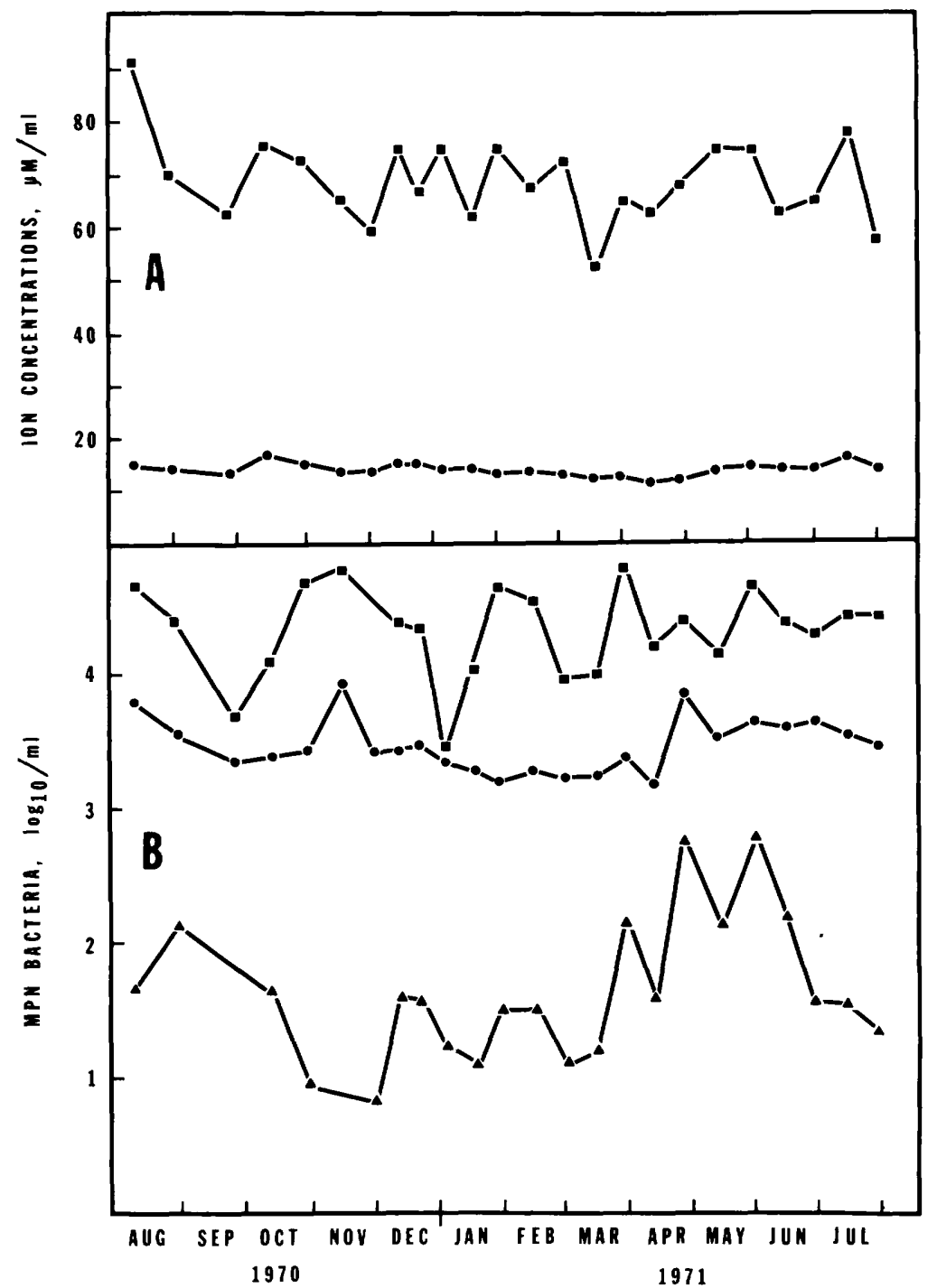

FIG. 1. Analysis of Brewer Pump effluent over a 1-year period. A, Ionic concentrations: •, sulfate ion; •, total iron. B, Bacterial populations: -, iron-oxidizing chemolithotrophs; •, heterotrophs; ^, sulfur-oxidizing chemolithotrophs.

aerobic, unable to grow under a Vaspar seal, and catalase positive. The oxidase reaction was slow in development (i.e., greater than $10 \mathrm{~s}$ ), and the cultures were judged to be oxidase negative. The presence of a cytochrome system is indicated, however, by positive benzidine tests and sensitivities to sodium azide and sodium cyanide. Results of additional biochemical characteristics are presented in Table 5.

DNA base composition. Based on four representative strains, the average DNA base composition of the acid mine water heterotrophs was found to be $66.4 \%$ guanine plus cytosine (Table 6). The small standard deviation suggests that the isolates are members of the same population.

Taxonomy. Because of their morphology, nutrition, yellow colonial pigmentation, and nonfermentative nature, the heterotrophic bacteria isolated from acid mine water are believed to be members of the genus Flavobacterium. The isolates, however, do not conform to descriptions of other flavobacteria. Because of their ability to withstand a $\mathrm{pH}$ value of 2.6 , a new species, Flavobacterium acidurans, is thus proposed for these organisms.

Flavobacterium acidurans sp. n. (M. L. neut. 


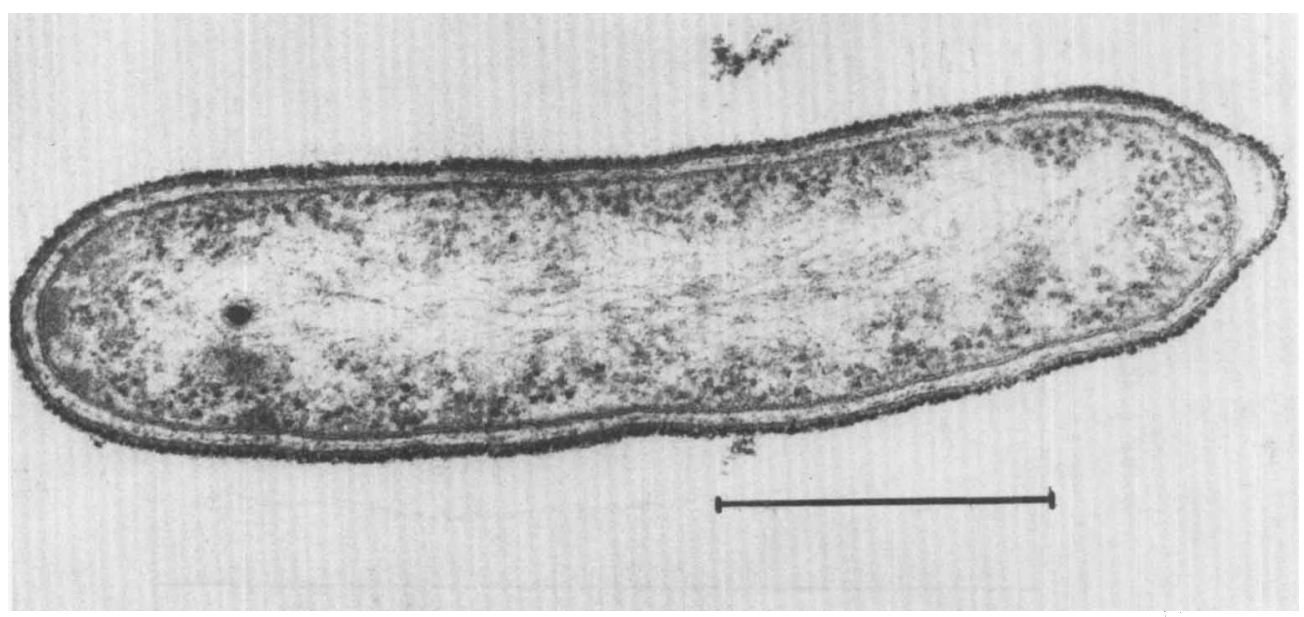

FIG. 2. Section of acid mine water heterotroph grown in TYE. Bar represents $0.5 \mu \mathrm{m}$.

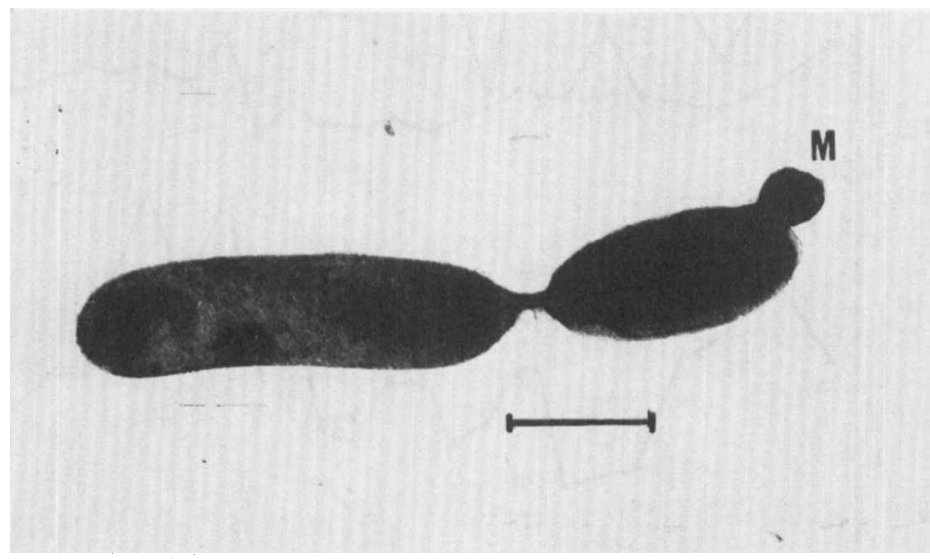

FIG. 3. Uranyl acetate-stained acid mine water heterotroph displaying multiple constrictions. Note mini-cell (M). Bar represents $0.5 \mu \mathrm{m}$

TABLE 2. Growth of acid mine water heterotrophs in various media

\begin{tabular}{l|c|c|c|c}
\hline \multirow{2}{*}{ Medium } & \multicolumn{2}{|c|}{ Trial I } & \multicolumn{2}{c}{ Trial II } \\
\cline { 2 - 5 } & Initial pH & Positive strains $^{a}$ & Initial pH & Positive strains $^{a}$ \\
\hline TYE & 6.0 & 15 & 6.0 & 15 \\
Casamino Acids, 1.0\% & 6.4 & 14 & 6.0 & 15 \\
Tryptone, 1.0\% & 7.3 & 0 & 6.0 & 15 \\
Soytone, 1.0\% & 7.1 & 0 & 6.0 & 15 \\
Proteose peptone, 1.0\% & 6.4 & 2 & 6.0 & 15 \\
Tryptose broth, 1.0\% & 7.2 & 1 & 6.0 & 15 \\
Nutrient broth & 6.8 & 8 & 6.0 & 15 \\
Heart infusion broth & 6.8 & 1 & 6.0 & 14 \\
Tryptic soy broth & 7.2 & 1 & 6.0 & 0 \\
Brain Heart Infusion & 6.9 & 0 & 1 \\
\hline
\end{tabular}

${ }^{a}$ Number of isolates displaying growth out of 15 examined. 
n. acidum, acid; L. part. adj. durans, resisting; M. L. adj. acidurans, acid resistant.).

Cells rod shaped, 0.3 to 0.6 by 1.0 to $3.0 \mu \mathrm{m}$, occurring singly or in pairs. Produce an asymmetric segregation of cytoplasmic material (mini-cells). Cell replication is by binary fission. Cells are aerobic, catalase positive, nonmotile, gram-negative, and nonsporeforming. Cells are oxidase negative, benzidine positive, and sensitive to sodium azide and potassium cyanide. Cells are slow growing, with turbidity or colonies evident after approximately 1 week of incubation. Mature colonies develop within 4 weeks with a diameter of $1 \mathrm{~mm}$ and a pale yellow, water-insoluble pigment. Growth occurs between 20 to $30 \mathrm{C}$; poor (seven strains) or no growth at $37 \mathrm{C}$. In laboratory media, growth occurs at $\mathrm{pH} 4.5$ to 6.5 ; growth occurs in acid mine water at $\mathrm{pH}$ 2.6. Cells maintain their viability when incubated at $25 \mathrm{C}$ in non-nutritive solutions at $\mathrm{pH} 2.6$ for periods as long as 1 month.

Tween 60 is hydrolyzed. Nitrate not reduced to nitrite. Xanthine and tyrosine are not decomposed. Indole and hydrogen sulfide are not produced. No growth in the presence of $3.0 \% \mathrm{NaCl}$. No acid from carbohydrates and polyalcohols. $\alpha$-Ketoglutarate is utilized as a sole carbon source in a mineral salts solution; there is no growth with pyruvate, acetate, oxalacetate, or benzoate and variable utilization of oxalate ( 2 strains), citrate ( 1 strain), malate (14 strains), and succinate (14 strains).

Ornithine, proline, and lysine are utilized as sole sources of carbon and nitrogen in mineral salts solutions; there is variable utilization of aspartate (6 strains), glutamate (11 strains), and arginine ( 5 strains), but no growth with other amino acids, purines, pyrimidines, or ethylamine. Sensitive to neomycin, polymyxin B, penicillin, terramycin, and vibriostatic agent $0 / 129$; variable sensitivity to bacitracin (11 strains). The DNA base composition is $66.4 \mathrm{~mol}$
TABLE 3. Temperature and $\mathrm{pH}$ ranges for growth of acid mine water heterotrophs in TYE

\begin{tabular}{|c|c|}
\hline Condition & Positive strains ${ }^{a}$ \\
\hline \multicolumn{2}{|c|}{ Temperature $(\mathrm{C})^{b}$} \\
\hline $10 \ldots \ldots \ldots$ & $\ldots \ldots 10$ \\
\hline $20 \ldots \ldots$ & $\ldots \ldots 15$ \\
\hline $30 \ldots \ldots$ & $\ldots \ldots 15$ \\
\hline $37 \ldots \ldots$ & $\ldots \ldots 7$ \\
\hline $45 \ldots \ldots \ldots$ & $\ldots \ldots 0$ \\
\hline \multicolumn{2}{|l|}{$\mathrm{pH}^{c}$} \\
\hline$\ldots \ldots$ & $\ldots 0$ \\
\hline $4.0 \ldots \ldots$ & $\ldots \ldots 11$ \\
\hline $4.5 \ldots \ldots$ & $\ldots \ldots 15$ \\
\hline $6.5 \ldots \ldots$ & $\ldots \ldots 15$ \\
\hline $7.0 \ldots \ldots$ & $\ldots \ldots 11$ \\
\hline $7.5 \ldots \ldots$ & $\ldots \ldots 0$ \\
\hline
\end{tabular}

${ }^{a}$ Number of isolates displaying growth out of 15 examined.

$b$ Medium at initial pH 6.0.

${ }^{c}$ Incubation at $20 \mathrm{C}$.

$\%$ guanine plus cytosine. Habitat is acidic water from a West Virginia coal mine.

Type strain. The type strain, number 1-51-22, has been deposited with the American Type Culture Collection under the number 27383. Cells of this strain are rod shaped, 0.3 to 0.6 by 1.0 to $3.0 \mu \mathrm{m}$, aerobic, nonmotile, gram-negative, and nonsporeforming. The DNA base composition is $66.3 \mathrm{~mol} \%$ guanine plus cytosine. Cell division is constrictive with the occasional formation of mini-cells. Growth occurs in acid mine water at $\mathrm{pH} 2.6$, and viability is maintained for at least 1 month in non-nutritive solutions at $\mathrm{pH} 2.6$.

Pale yellow colonies develop on solid media (pH 6.0) within 4 weeks with a diameter of 1 $\mathrm{mm}$. Growth at $20 \mathrm{C}$ and $30 \mathrm{C}$; no growth at 37 C. Cultures are catalase positive, oxidase negative, sensitive to sodium azide and potassium cyanide, and display a positive benzidine test.

TABLE 4. Growth of acid mine water isolate 1-51-22 under replacement culture conditions at pH 2.6 $6^{a}$

\begin{tabular}{l|c|c|c}
\hline \multicolumn{1}{c|}{ Medium $^{b}$} & Day $0^{c}$ & Day 13c & Population change $^{d}$ \\
\hline Distilled water & $2.3 \times 10^{6}$ & $3.3 \times 10^{4}$ & -98.6 \\
9K & $1.3 \times 10^{6}$ & $1.3 \times 10^{3}$ & -99.9 \\
Acid mine water & $3.3 \times 10^{6}$ & $7.0 \times 10^{6}$ & +112.1 \\
\hline
\end{tabular}

${ }^{a}$ At four intervals during incubation, $20 \%$ of the contents of each flask was removed and replaced with sterile medium of similar composition. Thus, $60 \%$ of the original contents of each flask was ultimately discarded.

$b$ Each medium was initially adjusted to $\mathrm{pH} 2.6$ with sulfuric acid.

$c$ Cells per milliliter as determined by five-tube MPN series in TYE.

$d$ Expressed as a percent of the initial population. 
TABLE 5. Biochemical characteristics of Flavobacterium acidurans

\begin{tabular}{|c|c|c|c|c|c|}
\hline Test & $\begin{array}{l}\text { Positive } \\
\text { strains }^{a}\end{array}$ & $\begin{array}{c}\text { Type strain } \\
(\text { ATCC } 27383)^{b}\end{array}$ & Test & $\begin{array}{l}\text { Positive } \\
\text { strains }^{a}\end{array}$ & $\begin{array}{c}\text { Type strain } \\
\left(_{(A T C C ~ 27383)^{b}}\right.\end{array}$ \\
\hline Phosphatase & 15 & + & Acid from: & & \\
\hline Nitrate reduction & 0 & - & Glycerol & 0 & - \\
\hline Decomposition of: & & & Arabinose & 0 & - \\
\hline Tyrosine & 0 & - & Ribose & 0 & - \\
\hline Xanthine & 0 & - & Xylose & 0 & - \\
\hline Growth on: ${ }^{c}$ & & & Fructose & 0 & - \\
\hline Koser citrate medium & 0 & - & Galactose & 0 & - \\
\hline Litmus milk & 0 & - & Glucose & 0 & - \\
\hline Urea broth & 0 & - & Mannose & 0 & - \\
\hline Thioglycolate medium & 0 & - & Dulcitol & 0 & - \\
\hline TYE containing: & & & Inositol & 0 & - \\
\hline Sodium chloride $(1.0 \%)$ & 15 & + & Mannitol & 0 & - \\
\hline Sodium chloride $(3.0 \%)$ & 0 & - & Sorbitol & 0 & - \\
\hline Methyl red & 0 & - & Cellobiose & 0 & - \\
\hline Voges-Proskauer & 0 & - & Sucrose & 0 & - \\
\hline Production of: & & & Lactose & 0 & - \\
\hline Indole & 0 & - & Maltose & 0 & - \\
\hline Hydrogen sulfide & 0 & - & Melibiose & 0 & - \\
\hline Hydrolysis of: & & & Raffinose & 0 & - \\
\hline Cellulose strip & 0 & - & Utilization of $:^{e}$ & & \\
\hline Gelatin $(3.0 \%)$ & 0 & - & Alanine & 0 & - \\
\hline $\operatorname{Starch}(0.2 \%)$ & 0 & - & Glycine & 0 & - \\
\hline Tween $60(1.0 \%)$ & 15 & + & Serine & 0 & - \\
\hline Utilization of: ${ }^{d}$ & & & Threonine & 0 & - \\
\hline Oxalate & 2 & - & Leucine & 0 & - \\
\hline Citrate & 1 & - & Isoleucine & 0 & - \\
\hline Pyruvate & 0 & - & Methionine & 0 & - \\
\hline Acetate & 0 & - & Aspartate & 6 & - \\
\hline Malate & 14 & + & Glutamate & 11 & + \\
\hline Succinate & 14 & + & Ornithine & 15 & + \\
\hline$\alpha$-Ketoglutarate & 15 & + & Proline & 15 & + \\
\hline Oxalacetate & 0 & - & Lysine & 15 & + \\
\hline Benzoate & 0 & - & Arginine & 5 & - \\
\hline Sensitivity to: & & & Tryptophane & 0 & - \\
\hline Bacitracin, 10 units & 11 & + & Phenylalanine & 0 & - \\
\hline Neomycin, $30 \mu \mathrm{g}$ & 15 & + & Histidine & 0 & - \\
\hline Polymyxin B, 300 units & 15 & + & Asparagine & 0 & - \\
\hline $0 / 129$ Crystals & 15 & + & Adenine & 0 & - \\
\hline Penicillin, 10 units & 15 & + & Thymine & 0 & - \\
\hline Terramycin, $50 \mu \mathrm{g}$ & 15 & + & Uracil & 0 & - \\
\hline Autotrophic growth on: & & & Cytosine & 0 & - \\
\hline Sulfur & 0 & - & Ethylamine & 0 & - \\
\hline Thiosulfate & 0 & - & & & \\
\hline Ferrous iron & 0 & - & & & \\
\hline
\end{tabular}

${ }^{a}$ Number of isolates displaying a positive result out of 15 examined.

$b+$, positive reaction; - , negative reaction.

${ }^{c}$ Media adjusted initially to $\mathrm{pH} 6.0$

${ }^{d}$ Utilization as sole carbon source.

${ }^{e}$ Utilization as sole source of carbon and nitrogen.

Additional biochemical characteristics of the type strain are presented in Table 5 .

\section{DISCUSSION}

In this study, a population of gram-negative, heterotrophic bacteria was demonstrated in acid mine water. Isolates from this population were sensitive to a range of antimicrobial compounds. Of interest was the inhibition of growth by $0 / 129$, a vibriostatic agent. In this connection, certain marine Flavobacterium and Cytophaga species are reported to be sensitive to the compound (10); members of the genus Pseudomonas are considered resistant (26).

Based on their Gram reaction, yellow water- 
TABLE 6. Deoxyribonucleic acid base composition of acid mine water heterotrophs

\begin{tabular}{l|c|c}
\hline \multicolumn{1}{c|}{ Strain no. } & $\begin{array}{c}\text { CsCl density } \\
\left(\mathrm{g} / \mathrm{cm}^{3}\right)\end{array}$ & $\begin{array}{c}\text { GC content } \\
(\mathrm{mol} \%)\end{array}$ \\
\hline $1-39-26$ & 1.725 & 65.8 \\
$1-42-12$ & $\begin{array}{l}1.724 \\
1.726\end{array}$ & 67.3 \\
$1-47-11$ & 1.726 & 66.3 \\
$1-51-22$ & 1.725 & 66.3 \\
& 1.725 & \\
Mean & 1.725 & 66.4 \\
Standard deviation & \pm 0.0006 & \pm 0.6 \\
\hline
\end{tabular}

${ }^{a} \mathrm{GC}$ content, guanine plus cy tosine.

insoluble pigmentation, nonfermentative nature, and lack of motility, the isolates have been placed within the genus Flavobacterium. This generic designation is further supported by a guanine plus cytosine content of $66.4 \mathrm{~mol} \%$, a value which correlates well with the results for four Flavobacterium species as reported by Marmur et al. (18). However, in this context, there is considerable variation within the genus (11). For example, DeLey and van Muylem (6) reported guanine plus cytosine values of marine Flavobacterium isolates from 35.6 to $40.6 \mathrm{~mol}$ $\%$. Further, the reisolated type species, $F$. aquatile, displays characteristics typical of Cytophaga species $(20,32)$. This latter genus has been eliminated from consideration in the present study since gliding motility was never observed with the acid-water isolates. On the basis of other morphological, physiological, and ecological considerations, a new species, $F$. acidurans, is proposed for the acid mine water isolates.

The formation of mini-cells by $F$. acidurans was of interest. Such structures have been noticed by other workers in Escherichia coli (1) and in a strain of Erwinia amylovora which had been induced to grow filamentously (12). While all bacteria now known to display mini-cells fall within the order Eubacteriales, little taxonomic value has been attached to them in the present work. It is conceivable, for example, that their presence might merely reflect a cellular response to suboptimal growth conditions.

The occurrence of heterotrophic microorganisms in acid mine water has been reported previously. Ehrlich (9) and Dugan et al. (8) isolated several heterotrophic microorganisms from the acidic effluents of copper and coal mines, respectively. In the latter work, a Bacillus species considered to be the primary source of "acid streamers" was described. Neither streamers nor gram-positive bacilli were found in the acid-water samples, however. In that same report five gram-negative, heterotrophic, bacterial isolates were also described. Although these isolates were unable to be subcultured for more than three transfers, they nonetheless resembled $F$. acidurans by their inability to ferment carbon compounds.

$F$. acidurans was enumerated in samples collected over a 1-year period at a level exceeding $10^{3}$ cells per ml. They thus constituted the second most dominant population after the iron-oxidizing thiobacilli in this acid ecosystem. The relatively stable numerical level observed suggests that they were either being continually leached into the water serviced by the pump or that they were multiplying in the acid water at a rate that was balanced by the outflow of the pumped water. As a result of their ability to grow in acid mine water in the laboratory, and because of the constant temperature, ion concentrations, and flow rates of the pump effluent, the latter possibility seems more attractive at present. Although the source of carbon for the heterotrophs in acid mine water is unknown, organic compounds leached from the soil above or organic matter released as waste material by the iron-oxidizing thiobacilli are two possibilities. That such crossfeeding might occur has been suggested but never demonstrated (8).

\section{ACKNOWLEDGMENTS}

I thank the Microbiology Department, West Virginia University Medical Center, and especially H. G. Voelz for permission and guidance in the use of their electron microscopy facilities. The determinations of deoxyribonucleic acid base compositions by $M$. Mandel of the M. D. Anderson Hospital, Houston, Texas, are also gratefully acknowledged.

This investigation was supported by National Science Foundation grant GB-27518.

\section{REPRINT REQUESTS}

Address requests for reprints to: Dr. Wayne N. Millar, 401 Brooks Hall, College of Agriculture and Forestry, West Virginia University, Morgantown, W. Va. 26506.

\section{LITERATURE CITED}

1. Adler, H. I., W. D. Fisher, A. Cohen, and A. A. Hardigree. 1967. Minature Escherichia coli cells deficient in DNA. Proc. Nat. Acad. Sci. U.S.A. 57:321-326.

2. Barber, M., and S. W. A. Kuper. 1951. Identification of Staphylococcus pyogenes by the phos- 
phatase reaction. J. Pathol. Bacteriol. 63:65-68.

3. Charles, A. M., and I. Suzuki. 1966. Mechanism of thiosulfate oxidation by Thiobacillus novellus. Biochim. Biophys. Acta 128:510-521.

4. Colmer, A. R., and M. E. Hinkle. 1947. The role of microorganisms in acid mine drainage: a preliminary report. Science 106:253-256.

5. Deibel, R. H., and J. B. Evans. 1960. Modified benzidine test for the detection of cytochromecontaining respiratory systems in microorganisms. J. Bacteriol. 79:356-360.

6. DeLey, J., and J. van Muylem. 1963. Some applications of deoxyribonucleic acid base composition in bacterial taxonomy. Antonie van Leeuwenhoek J. Microbiol. Serol. 29:344-358.

7. Dugan, P. R., C. B. MacMillan, and R. M. Pfister. 1970. Aerobic heterotrophic bacteria indigenous to $\mathrm{pH} 2.8$ acid mine water: microscopic examination of acid streamers. J. Bacteriol. 101:973-981.

8. Dugan, P. R., C. B. MacMillan, and R. M. Pfister. 1970. Aerobic heterotrophic bacteria indigenous to $\mathrm{pH} 2.8$ acid mine water: predominant slimeproducing bacteria in acid streamers. J. Bacteriol. 101:982-988.

9. Ehrlich, H. L. 1963. Microorganisms in acid drainage from a copper mine. J. Bacteriol. 86:350-352.

10. Hayes, P. R. 1963. Studies on marine flavobacteria. J. Gen. Microbiol. 30:1-19.

11. Hill, L. R. 1966. An index to deoxyribonucleic acid base compositions of bacterial species. J. Gen. Microbiol. 44:419-437.

12. Huang, Pi-Yu, and R. N. Goodman. 1970. Morphology and ultrastructure of normal rodshaped and filamentous forms of Erwinia amylovora. J. Bacteriol. 102:862-866.

13. Hugh, R., and E. Leifson. 1953. The taxonomic significance of fermentative versus oxidative metabolism of carbohydrates by various gram negative bacteria. J. Bacteriol. 66:24-26.

14. James, N. 1958. Soil extract in soil microbiology. Can. J. Microbiol. 4:363-370.

15. Kellenberger, E., A. Ryter, and J. Sechaud. 1958. Electron microscope study of DNA-containing plasms. II. Vegetative and mature phage DNA as compared with normal bacterial nucleoids in different physiological states. J. Biophys. Biochem. Cytol. 4:671-678.

16. Kovacs, N. 1956. Identification of Pseudomonas pyocyanea by the oxidase reaction. Nature (London) 178:703.

17. Luft, J. H. 1961. Improvements in epoxy resin embedding methods. J. Biophys. Biochem. Cytol. 9:409-414.
18. Marmur, J., S. Falkow, and M. Mandel. 1963. New approaches to bacterial taxonomy. Annu. Rev. Microbiol. 17:329-372.

19. Meynell, G. G., and E. Meynell. 1965. Theory and practice in experimental bacteriology. Cambridge University Press, Cambridge, England.

20. Mitchell, T. G., M. S. Hendrie, and J. M. Shewan. 1969. The taxonomy, differentiation and identification of Cytophaga species. J. Appl. Bacteriol. 32:40-50.

21. Postgate, J. R. 1963. Versatile medium for the enumeration of sulfate-reducing bacteria. Appl. Microbiol. 11:265-267.

22. Reynolds, E. S. 1963 . The use of lead citrate at high $\mathrm{pH}$ as an electron-opaque stain in electron microscopy. J. Cell. Biol. 17:208-212.

23. Santer, M., J. Boyer, and U. Santer. 1959. Thiobacillus novellus. I. Growth on organic and inorganic media. J. Bacteriol. 78: 197-202.

24. Schildkraut, C. L., J. Marmur, and P. Doty. 1962. Determination of the base composition of deoxyribonucleic acid from its buoyant density in $\mathrm{CsCl}$. J. Mol. Biol. 4:430-433.

25. Schnaitman, C., and D. G. Lundgren. 1965. Organic compounds in the spent medium of Ferrobacillus ferrooxidans. Can. J. Microbiol. 11:23-27.

26. Shewan, J. M., W. Hodgkiss, and J. Liston. 1954. A method for the rapid differentiation of certain non-pathogenic, asporogenous bacilli. Nature (London) 173:208-209.

27. Silverman, M. P., and D. G. Lundgren. 1959. Studies on the chemoautotrophic iron bacterium Ferrobacillus ferrooxidans. I. An improved medium and a harvesting procedure for securing high cell yields. J. Bacteriol. 77:642-647.

28. Starkey, R. L. 1934. Cultivation of organisms concerned in the oxidation of thiosulfate. J. Bacteriol. 28:365-386.

29. Steel, K. J. 1961. The oxidase reaction as a taxonomic tool. J. Gen. Microbiol. 25:297-306.

30. Trautwein, K. 1921. Die Physiologie und Morphologie der facultativ Thionsaurebacterien (Omelianski). Zentralbl. Bakteriol. Parasitenkd. Infektionskr. Hyg. Abt. 2. Naturwiss. 53:513-548.

31. Tuttle, J. H., C. I. Randles, and P. R. Dugan. 1968. Activity of microorganisms in acid mine water. I. Influence of acid ters on aerobic heterotrophs of a normal si. J. Bacteriol. 95:1495-1503.

32. Weeks, O. B. 1969. Problems concerning the relationships of cytophagas and flavobacteria. $\mathrm{J}$. Appl. Bacteriol. 32:13-18. 